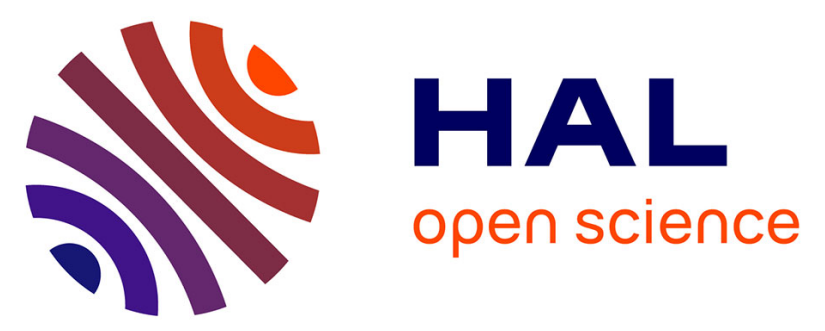

\title{
A new putative species in the Ectatomma ruidum complex (Formicidae: Ectatomminae) produces a species-specific distress call
}

Kenzy Peña Carrillo, María Cristina Lorenzi, Maxence Brault, Paul Devienne, Jean-Paul Lachaud, Gianni Pavan, Chantal Poteaux

\section{To cite this version:}

Kenzy Peña Carrillo, María Cristina Lorenzi, Maxence Brault, Paul Devienne, Jean-Paul Lachaud, et al. A new putative species in the Ectatomma ruidum complex (Formicidae: Ectatomminae) produces a species-specific distress call. Bioacoustics, 2021, pp.1-16. 10.1080/09524622.2021.1938226 . hal03357524

\section{HAL Id: hal-03357524 \\ https://hal.science/hal-03357524}

Submitted on 28 Sep 2021

HAL is a multi-disciplinary open access archive for the deposit and dissemination of scientific research documents, whether they are published or not. The documents may come from teaching and research institutions in France or abroad, or from public or private research centers.
L'archive ouverte pluridisciplinaire HAL, est destinée au dépôt et à la diffusion de documents scientifiques de niveau recherche, publiés ou non, émanant des établissements d'enseignement et de recherche français ou étrangers, des laboratoires publics ou privés. 


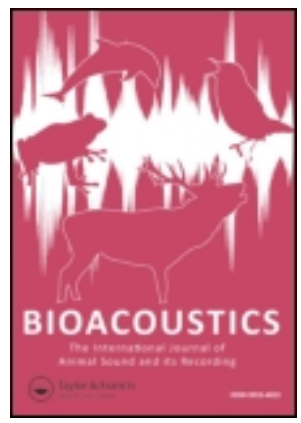

\section{A new putative species in the Ectatomma ruidum complex (Formicidae: Ectatomminae) produces a species-specific distress call}

\begin{tabular}{|c|c|}
\hline Journal: & Bioacoustics \\
\hline Manuscript ID & TBIO-2021-0005.R1 \\
\hline Manuscript Type: & Original Article \\
\hline $\begin{array}{r}\text { Date Submitted by the } \\
\text { Author: }\end{array}$ & 18-May-2021 \\
\hline Complete List of Authors: & $\begin{array}{l}\text { PEÑA CARRILLO, KENZY; Université Sorbonne Paris Nord, LEEC; Instituto } \\
\text { Nacional de Investigaciones Forestales Agricolas y Pecuarias, Campo } \\
\text { Experimental General Terán } \\
\text { Lorenzi, Maria Cristina; Université Sorbonne Paris Nord, Laboratoire } \\
\text { d'Ethologie Expérimentale et Comparée } \\
\text { Brault, Maxence; Université Sorbonne Paris Nord, Laboratoire d'Ethologie } \\
\text { Expérimentale et Comparée } \\
\text { Devienne, Paul; Université Sorbonne Paris Nord, Laboratoire d'Ethologie } \\
\text { Expérimentale et Comparée } \\
\text { Lachaud, Jean-Paul; El Colegio De La Frontera Sur, Depto. de } \\
\text { Conservación de la Biodiversidad; Université de Toulouse III, Centre de } \\
\text { Recherches sur la Cognition Animale, Centre de Biologie Intégrative } \\
\text { Pavan, Gianni; Università degli Studi di Pavia Dipartimento di Scienze } \\
\text { della Terra e dell'Ambiente, Dipartimento di Scienze della Terra e } \\
\text { dell'Ambiente } \\
\text { Poteaux, Chantal; Université Sorbonne Paris Nord, Laboratoire } \\
\text { d'Ethologie Expérimentale et Comparée }\end{array}$ \\
\hline Keywords: & ant acoustics, stridulations, stridulatory organ, species complex \\
\hline
\end{tabular}

\section{SCHOLARONE ${ }^{m}$ \\ Manuscripts}


A new putative species in the Ectatomma ruidum complex (Formicidae:

\section{Ectatomminae) produces a species-specific distress call}

4 Jean-Paul Lachaud ${ }^{3,4}$, Gianni Pavan ${ }^{5}$, Chantal Poteaux ${ }^{1}$

5 'LEEC-Laboratoire d'Ethologie Expérimentale et Comparée, Université Sorbonne Paris Nord,

6 Sorbonne Paris Cité, 99 avenue J.-B. Clément, 93430 Villetaneuse, France.

7 2INIFAP, Campo Experimental General Terán, km 31 carretera Montemorelos-China, 67400,

8 General Terán, N.L. México.

$9 \quad{ }^{3}$ Depto. de Conservación de la Biodiversidad, El Colegio de la Frontera Sur, Avenida

10 Centenario Km. 5.5, 77074 Chetumal, Quintana Roo, México.

$11{ }^{4}$ Centre de Recherches sur la Cognition Animale, Centre de Biologie Intégrative, Université

12 de Toulouse CNRS, UPS, 118 route de Narbonne, 31062 Toulouse Cedex 09, France.

$13{ }^{5}$ Centro Interdisciplinare di Bioacustica e Ricerche Ambientali, Dipartimento di Scienze della

14 Terra e dell'Ambiente, Università degli Studi di Pavia, Via Taramelli 24, 27100, Pavia, Italy.

15 Corresponding author: kenzy.p@gmail.com, ORCiD ID 0000-0003-0580-6700

16 


\section{Abstract}

18 Social insects communicate by using chemical, visual, tactile, and acoustic signals, including 19 stridulations. Ectatomma ruidum is a mainly Neotropical ant species complex that has faced 20 strong divergence at the genetic level; the species have a highly variable blend of cuticular 21 hydrocarbons and a relatively conserved morphology. Based on evidence for genetic and 22 chemical differentiation, we tested for variation in acoustic traits. We compared the 23 stridulations produced by the species E. ruidum sp. 2, sp. 3-4 and the new putative species $E$. 24 ruidum sp. 5, as well as the morphology of the stridulatory file. We found that the stridulations 25 produced by E. ruidum sp. 5 were statistically different from those of the other species in a 26 number of traits. The differences in stridulatory traits might rely more on the way the ants 27 produce the sound (rubbed area percentages) than on the morphology of the stridulatory file, 28 for which we did not find variation. Our results highlight the use of acoustic traits as potential 29 taxonomic tools for integrative taxonomic studies and suggest that the acoustic traits of $E$. 30 ruidum species complex have been subjected to selection.

31 Keywords: ants, acoustics, stridulations, stridulatory organ, species complex.

\section{Introduction}

33 Communication is an important feature of animal life that allows individuals to share 34 information and its efficiency is essential for social life (Hölldobler 1999; d'Ettorre and Moore 35 2008). In social insects and particularly in ants, the efficient communication system and the 36 social organization are the primary bases for their evolutionary success; the efficient 37 transmission of information allows them to regulate the functional division of castes, cooperate 38 in rearing immature stages, gather food, defend the nest, explore new foraging grounds, 39 establish territorial borders and reject foreigners (Hölldobler 1995). Apart from chemical cues, 40 social insects communicate by using visual, tactile, and vibro-acoustic signals, among them 41 stridulations (Hölldobler and Wilson 1990; Hölldobler 1999; Leonhardt et al. 2016). 
42 For stridulation production, insects use specialized devices or organs where opposite areas of 43 the exoskeleton serve as file and scraper (Masters et al. 1983). In ants, the stridulatory organ typically consists of a ridge (plectrum or scraper) located on the edge of the post-petiole, and a al. 2013).

51 For some taxa, the study of the stridulatory organs and/or the sounds they produce revealed 52 intra- or inter-species variation; for example, in mutillid wasps (Polidori et al. 2013), in ants 53 such as Messor (Grasso et al. 1998) and Neoponera apicalis (=Pachycondyla) (Ferreira et al. 54 2010), and in some species of the Myrmicinae subfamily (Castro et al. 2015), underlying their potential as taxonomic tools.

Ectatomma ruidum Roger is a mainly Neotropical ant species that exhibits the peculiar intraspecific behavior named cleptobiosis (food thievery between neighboring colonies), and that was recently discovered to be a species complex (Aguilar-Velasco et al. 2016). Recent molecular studies have shown that some species within the complex have faced selection in 
67 species (Aguilar-Velasco et al. 2016), while knowledge about the acoustic organ morphology and characteristics of the sounds produced are scarce.

In E. ruidum, stridulations consist of sequences of pulse-trains organized in two subunits (disyllabic chirps) composed by series of pulses with opposite phases (Pavan et al. 1997). In a previous study (Pavan et al. 1997), the distress call of E. ruidum was analyzed in a limited sample of workers from a single population in the south of Mexico (state of Chiapas), at a time when the taxonomic complexity of the group and the existence of different species within the complex were unacknowledged.

If communication systems are targets of selection (Endler 1992), we expected that, based on the evidence that the E. ruidum species complex exhibits high variation in their chemical communication system between and within species, divergence was also apparent in acoustic signaling. Indeed, it was shown that bush-cricket populations characterized by distinctive song types also diverge in their cuticular lipid proportions (Dutta et al. 2018). In addition, we hypothesized that sound differences, if any, might be caused by morphometric differences in the organ used to produce the sound. To test these hypotheses, we coupled the analysis of stridulation recordings (distress call) with that of morphometry of the stridulatory file, to investigate whether acoustic signals diverged between the species E. ruidum sp. 2, sp. 3-4 and the newly reported E. ruidum sp. 5.

\section{Materials and Methods}

\section{Collection of ants}

7 The ants of the E. ruidum complex were collected in the states of Oaxaca and Quintana Roo (Mexico), and in Cali (Colombia) (Table 1); colonies from the same collection site were at least 1-2 $\mathrm{m}$ distant from each other. It is worth pointing that the different species of these ants cannot be distinguished in the field and that collection sites are often difficult to reach. Therefore, only after molecular or chemical investigations in the lab ants can be assigned to one of the species, 
92 making it difficult to plan the number of colonies per species and per population to collect 93 during field trips. In particular, no replicate populations are possible for E. ruidum sp. 5, because 94 up to now only one population has been identified (Pena-Carrillo et al 2021).

\section{Laboratory rearing and species identification}

96 In laboratory, all colonies were kept in artificial nests at $25 \pm 1^{\circ} \mathrm{C}$, with a photoperiod of $12 \mathrm{~h}$ 97 L: $12 \mathrm{~h} \mathrm{D}$ and a relative humidity of $40 \%$, they were fed three times per week with a mixture 98 of honey, apple and crickets, and were given with water ad libitum.

99 The colonies from Coyula and Cali were identified as E. ruidum sp. 2, and those from Puerto 100 Escondido, Piedras Negras and Mazunte as E. ruidum sp. 3-4 by Meza-Lázaro et al. (2018).

101 The colonies from Punto 3 and Huaxpaltepec were identified as E. ruidum sp. 3-4 and sp. 5, 102 respectively by Peña-Carrillo et al. (2021), and those from Puerto Morelos as E. ruidum sp. 2 103 by Poteaux et al., based on barcoding sequences (COI gene) (unpublished data).

\section{Stridulation recording and analysis}

105 We randomly choose 85 workers from 13 colonies of three putative species of the E. ruidum 106 complex for the acoustic analyses (4-5 colonies per species, see Table 1$)$.

107 We recorded the sounds produced by individual ants separated from their nestmates in a room 108 isolated from environmental sounds and electric interferences; experimental conditions were 109 the same in terms of temperature (room temperature $25-28{ }^{\circ} \mathrm{C}$ ) and humidity $(40 \%)$. To 110 induce the distress call, we held each individual by the thorax with soft entomological forceps 111 and placed it at $1 \mathrm{~cm}$ from the ultrasonic microphone for at least one minute, following Pavan 112 et al. (1997) and Ferreira et al. (2010). Inducing the distress call and getting homogenous series 113 of chirps was time consuming, as often E. ruidum individuals exhibited a freezing behavior in 114 which the ants retracted their limbs and stayed immobile with their bodies hunching after 115 disturbance (Cupul-Magaña 2009). We used the ultrasonic USB microphone UltraMic 250 by 116 Dodotronic, and the Sea Pro 2.0 software package developed by Pavan G. at CIBRA for sound 
117 recording and real-time display. All recordings were performed at 250k sampling rate with 16

118 bits dynamic range according to the AD converter of the microphone. After sound recording,

119 ants were killed by freezing and kept in $95 \%$ ethanol for the analysis of the stridulatory file

120 morphology.

121 For each ant we analyzed five chirps which were selected only if they were included in 122 continuous and homogenous series of chirps, and if they presented the disyllabic structure 123 described by Pavan et al. (1997), that is, two pulse trains with opposite phase, separated by a 124 gap. Using the software Raven Lite (Bioacoustics Research Program, 2016), we measured the 125 following variables: chirp duration, duration of forward phase, inter-chip duration (GAP), 126 duration of backward phase and frequency range (intended as the upper limit of frequency range 127 of the pulses). Then, by using the "seewave" package (Sueur et al. 2008) in RStudio (Version 128 3.5.2), we counted the number of pulses in the forward and backward phase of the disyllabic 129 chirps. We also calculated the total number of pulses (sum of pulses in the forward and 130 backward phase), the chirp rate (number of chirps / second) and the average pulse rate of the 131 forward and backward phase (number of pulses / second).

132 Morphometry of the stridulatory file

133 After the sound recording, 42 out of the 85 workers used for the acoustical analyses were 134 dissected under a stereoscope and we took pictures of their stridulatory file with a Leica S440 135 Scanning Electron Microscope (SEM). For each ant, the fourth abdominal segment of the gaster 136 containing the stridulatory organ was cleaned by submersion in distilled water in an ultrasonic 137 bath for approximately five minutes, and then air-dried and fixed in a drop of silver plate over 138 an aluminum stub. Once fixed, the samples were oven-dried for two to three hours at $50{ }^{\circ} \mathrm{C}$, 139 and coated with an 8-nm mixture of gold-palladium for being photographed with the SEM.

140 Using the software Image J 1.51 (Schneider et al. 2012), we measured the following 141 morphometric variables according to Ferreira et al. (2010): thorax length, total length of 
142 stridulatory file (TL), maximal width (MW), $1^{\text {st }}, 2^{\text {nd }}$ and $3^{\text {rd }}$ quartile widths (Q1, Q2, Q3, 143 respectively), number of ridges and inter-ridge distance (ID) in the median portion of the

144 stridulatory file (for data analyses, inter-ridge distance was the average of five measures).

\section{Statistical analyses}

146 We reduced the number of acoustic and morphologic variables by performing separate Principal 147 Component Analyses (PCA) for acoustic and morphometric data. Then, we tested for 148 differences in PC values between species by running Generalized Linear Mixed Models 149 (GLMMs) for normally distributed data (identity link). In the GLMM, either the morphometric 150 or acoustic principal components (PCs) were the response variables, and species the fixed

151 factor; colony and population were used as random factors to account for the non-independence 152 of data. For the GLMM on acoustic data, individual identity was also used as a random factor 153 to account for non-independence of the measures from the same individual thus assuming a 154 different "baseline" measure for each subject. While the statistical comparison tests assess the 155 difference within and between individuals (or population or species), by entering a random 156 factor in the model we also controlled for individual differences. Frequency range values were 157 excluded from our statistical analyses due to variations mostly related to changes in the 158 microphone / ant distance and orientation, then, only robust temporal measures were analyzed.

159 By combining the use of the acoustic and morphometric variables we calculated the percentage 160 of rubbed ridges ((number of pulses $\mathrm{x} 100)$ / total number of ridges) and the speed of the rubbing 161 movement (length of rubbed surface / chirp duration of forward or backward phase) for both

162 phases. We used these data to test for variation in the sounds produced among species by 163 performing the Kruskal-Wallis test and then we checked for pairwise differences using Mann164 Whitney test.

165 All statistical analyses were conducted with the software IBM SPSS version 23.

\section{Results}


167

168

169

170

171

172

173

174

175

176

177

178

179

180

181

182

183 PC2, which explained $18.5 \%$ of variance, summarized the duration of chirps (total chirp duration, duration of the forward phase and of the GAP duration) (Table 4) and did not discriminate among species $\left(\mathrm{GLMM}, \mathrm{F}_{2,426}=0.831 ; \mathrm{P}=0.436\right)$ (Figure 2).

Variation of the sounds: the link between stridulations and morphology

187 During the stridulation, the percentage of ridges rubbed was highly significantly different 188 among species (Kruskall-Wallis test: forward phase $-\mathrm{K}=11.34$, $\mathrm{df}=2, \mathrm{P}=0.003, \mathrm{~N}=37$, 189 backward phase $-\mathrm{K}=11.83, \mathrm{df}=2, \mathrm{P}=0.003, \mathrm{~N}=37$ ). Pairwise comparisons indicated that 190 the differences in the percentage of ridges rubbed by the ants E. ruidum sp. 5 were significant 191 compared to E. ruidum sp. 2 and sp. 3-4 (Forward phase rubbing - sp. 5 vs sp. 2: $\mathrm{U}=66, \mathrm{P}=$ 
$1920.002, \mathrm{~N}=19$; sp. 5 vs sp. 3-4: $\mathrm{U}=89, \mathrm{P}<0.0001, \mathrm{~N}=23$; Backward phase rubbing - sp. 5 vs

193 sp. 2 : $\mathrm{U}=63, \mathrm{P}=0.007, \mathrm{~N}=19$; sp. 5 vs sp. $3-4$ : $\mathrm{U}=87, \mathrm{P}<0.0001, \mathrm{~N}=23$; these differences

194 were still significant after correcting for multiple comparisons) (Figure 3). In comparison to $E$.

195 ruidum sp. 2 and sp. 3-4, the ants E. ruidum sp. 5 produced chirps at the lowest rate because

196 they rubbed a higher percentage of ridges (approximately the double) thus producing at least

$19750 \%$ more pulses (Table 2). Ants E. ruidum sp. 2 and sp. 3-4 rubbed a similar percentage of 198 ridges (Forward phase rubbing $-\mathrm{U}=113, \mathrm{P}=0.639, \mathrm{~N}=32$; Backward phase rubbing $-\mathrm{U}=$ $19984, \mathrm{P}=0.116, \mathrm{~N}=32$ ) (Tables 2 and 3, Figure 3). The three species stridulated at similar speed $200(\mathrm{~K}=3.496, \mathrm{df}=2, \mathrm{P}=0.174, \mathrm{~N}=37$, backward phase $-\mathrm{K}=5.557, \mathrm{df}=2, \mathrm{P}=0.062, \mathrm{~N}=37)$.

\section{Morphometric traits}

202 In all three species of the E. ruidum complex the stridulatory file was located at the anterior 203 edge of the first gastral segment of the abdomen (Figure 4).

204 The PCA performed on the morphological traits of the stridulatory file (Table 5) summarized 205 the overall variation in two principal components that together explained $67.4 \%$ of total 206 variance. PC1 (41\%) was mainly related to the variation in the width of the stridulatory file 207 (width of Q1, Q2 and maximal width, Table 6). PC2 (26.3\% of the variance) was associated to 208 the variation in the length of the stridulatory file, the number of ridges and the body size 209 (represented by thorax length) (Table 6). However, neither PC1 nor PC2 scores differed 210 significantly between species (GLMM, PC1: $\mathrm{F}_{2,39}=0.032, \mathrm{P}=0.97, \mathrm{PC} 2 ; \mathrm{F}_{2,39}=1.467, \mathrm{P}=$ 2110.24

212 Discussion

213 Our results show that worker ants belonging to E. ruidum sp. 5, the new putative species 214 recently reported by Peña-Carrillo et al. (2021), produce a distress call that differs from the 215 closely related species E. ruidum sp. 2, and sp. 3-4. To our knowledge, the acoustic 216 differentiation might rely mainly in in the way ants produce the sound (percentage of ridges 
217 rubbed by the plectrum during its movement), due to the similarity in the morphological traits 218 of the stridulatory files. However, although the difference in the acoustical traits is clear, the 219 lack of morphological differences of the stridulatory file between the species may need further 220 investigations.

221 Ant stridulations are involved in different behaviors. Solenopsis richteri ants stridulate when 222 they are alarmed, when they attack or are stressed (e.g., stress induced by holding the body of 223 the ants) (Hickling and Brown, 2000). In Atta cephalotes, workers use a distress call to attract 224 nestmates in rescue behavior when they are trapped under the soil (Markl, 1965); to attract ants 225 of other castes to fight against parasites, and to recruit nestmates when cutting leaves to 226 provision the colony fungi (Roces et al. 1993; Hölldobler, 1999). In velvet ants, distress calls 227 have been interpreted as warning signals against predators (Wilson et al. 2012, 2018; Pan et al. 228 2017), and a possible role in intra-specific communication has been mentioned (Torrico229 Bazoberry and Muñoz 2019). In E. ruidum, stridulations may serve as a modulatory signal 230 enhancing short-range recruitment of nestmates during collective strategies of prey retrieval 231 (Schatz et al. 1997), although focused experiments are needed to confirm this hypothesis. 232 According to Tschuch and Brothers (1999), non-resonant structures as the stridulatory organ 233 serve for short-range intra and interspecific communication; however, their sound power level 234 might not be strong enough to be effective over a distance.

235 In the event that E. ruidum sp. 5 lived in sympatry with other species of the complex, its distress 236 call could reflect divergent selection faced by the species in the presence of another species, 237 although the benefit of producing species-specific distress calls might be argued. Up to now, 238 whether E. ruidum sp. 5 is sympatric with other species of the complex is unknown.

239 Acoustic signaling has been used as a means to distinguish species because calls have emerged 240 as species-specific in different groups of insects, such as homopterans (Claridge, 1985), 241 lacewings (Henry et al. 1993), flies (Ritchie and Gleason 1995), beetles (Kasper and 
242 Hirschberger 2005) and bush crickets (Chobanov et al. 2013; Zanthiev et al. 2017). For all these 243 taxa, sound variation reflected selection on calls serving crucial communication functions, such 244 as courtship calls. For instance, Kasper and Hirschberger (2005) studied the behavioral context 245 and acoustic structure of calls produced by different species of Aphodius bettles, as well as the 246 morphology of their stridulatory organs. They found that the beetles produced calls when they 247 were disturbed, and that males produced species-specific calls when they encountered females 248 in an experimental dung arena; the stridulatory organs of the beetles also presented species249 specific morphology.

250 In coevolutionary relationships, calls used for acoustic mimicry are also species-specific, as 251 reported in lycaenid butterflies among which some species spend their larval stages as parasites 252 in ant nests. Riva et al. (2016) studied the acoustic repertoire of parasitic and non-parasitic 253 lycaenid larvae and found that typically all species produced species-specific calls and that the 254 calls of parasitic species revealed their association with different species of host ants. That is, 255 the calls of parasitic species had a higher number of harmonics which overlapped their hosts' 256 frequency range, which in turn potentially increased their chances to stimulate host ant receptors 257 and get food from the ants.

258 The analysis of distress calls has also been useful to reveal inter-specific variation. For example, 259 Polidori et al. (2013) compared the distress calls and morphology of the stridulatory file of 260 European velvet ants from different subfamilies and genera. They found acoustic differences 261 between the species, but statistics for all the studied species weakly supported the species262 specific association of sound variation with morphological variance. Carlos et al. (2014) 263 analyzed the stridulations and the stridulatory file of the workers from three species of Attini 264 ants and reported that the chirps' duration was species-specific. Their study demonstrated 265 stridulations as an efficient taxonomic tool for species identification in the Attini tribe. Distress 266 calls are useful taxonomic tools for cryptic species delimitation. By studying a set of cryptic 
267 species within the Neoponera apicalis complex, Ferreira et al. (2010) found that the calls of 268 sympatric species differed from each other, probably because of their sympatric interactions. In 269 addition, in combination with the distress calls, the analysis of the stridulatory file and 270 mitochondrial DNA sequences highlighted the cryptic species (Ferreira et al. 2010).

271 In comparison to the species of the $N$. apicalis complex, up to now there is no evidence whether 272 the species of E. ruidum are sympatric, but populations of the different species live close 273 geographically. Yet, there seems to be no clear association between geographic distance and 274 sound differentiation. According to Aguilar-Velasco et al. (2016), E. ruidum sp. 2 and sp. 3-4 275 are located at fewer than $25 \mathrm{~km}$ of distance from each other, and the current results show that 276 their stridulations did not differ significantly. In contrast, E. ruidum sp. 2 and sp. 3-4 277 stridulations differed from that of E. ruidum sp. 5, whose colonies were located within the 278 distribution range of E. ruidum sp. 3-4 (with the closest population separated by $\sim 60 \mathrm{~km}$ ), and 279 close to a population of E. ruidum sp. 2 (located less than $20 \mathrm{~km}$ away, Peña-Carrillo et al. 280 2021).

281 In some insects, morphological structures for sound production differ more than sounds 282 between species (Schmitt 1994; Schmitt and Traue 1990) while in other cases, the opposite was 283 suggested. For example, like our results suggest, Grasso et al. $(1998,2000)$ found that the 284 stridulations produced by the different castes of Messor ants varied not because of 285 morphometry, but because of the way the ants produce the sound, like the speed of the 286 movement and the duration of the gaps between phases in the chirps, as our results also suggest. 287 Although the limited sampling used for morphological analyses did not allow us to detect any 288 significant variation in the structure of the stridulatory file of the workers, the combination of 289 acoustic and morphological traits generated inter-specific variation in E. ruidum stridulation. 290 Furthermore, the same acoustic traits that discriminated E. ruidum sp. 5 from the other species 291 (this study) also discriminated between cryptic species of Neoponera ants (namely chirp 
292 duration, the number of pulses and velocity of the rubbing movement) (Ferreira et al. 2010), 293 supporting the use of acoustic traits in integrative taxonomic studies. In fact, diverse taxa can 294 be diagnosed through their acoustic production. For example, birds produce distinct songs 295 which allow species identification, even when they are otherwise very similar morphologically 296 (Rheindt et al. 2008; Mahoney et al. 2020), and sound production is used to identify species in 297 marine mammals (Oswald et al. 2007; Bauman-Pickering et al. 2013; Lin et al. 2014), and in 298 insects such as crickets and katydids (Lehmann et al. 2014; Brizio et al. 2020; Mc Neil and 299 Grozinger 2020). In ants the examples are less common (Ferreira et al. 2010), but do exist.

300 In the E. ruidum, a striking divergence was found in the olfactory cues that play a significant 301 role in nestmate discrimination (cuticular hydrocarbons) in most of the populations of the 302 species complex, including E. ruidum sp. 5 (Peña-Carrillo et al. 2021). Furthermore, in $E$. 303 ruidum sp. 5, the phylogenetic tree based on mitochondrial sequences supported its 304 differentiation from the species E. ruidum sp. 2 and 3-4 (Peña-Carrillo et al. 2021). Therefore, 305 differentiation in the acoustical characteristics of the distress call of E. ruidum sp. 5 could be 306 expected in a scenario where the communication system of this species was under higher 307 diverging selection pressure than those of E. ruidum sp. 2 and sp. 3-4. However, studies 308 including all the species of the complex are needed to know whether the variation of the distress 309 call is exclusive to E. ruidum sp. 5.

310 Whatever the causes of the divergence of the distress call of E. ruidum sp. 5 from that of $E$. 311 ruidum sp. 2 and sp. 3-4, these results highlight that E. ruidum sp. 5 differs not only chemically 312 and genetically (Peña-Carrillo et al. 2021), but also acoustically. Adding evidence that this 313 taxon evolved separately from the other species of the complex, these results offer another 314 example of selection pressures acting on the communication system of ants.

\section{Acknowledgments}


316 This study is part of the PhD project of KIPC supported by a CONACyT-French government

317 scholarship. Thanks to Miguel Quiroz, Franco Robles Guerrero, Rubí Meza-Lázaro, Gabriela

318 Pérez-Lachaud, Alejandro Zaldivar Riverón and Carlos Santamaría for their help during the

319 field trips in Mexico and Colombia. We thank Ovidiu Brinza from the LSPM-CNRS for his 320 assistance while taking SEM photos and Christophe Féron for his valuable help with the scripts

321 employed for seewave analyses.

\section{Ethical statement}

323 Our study followed the institutional and national ethical guidelines for scientific research in

324 Mexico, Colombia and France. The species used in the experiments are not endangered or 325 protected in Mexico and Colombia and the collection of live ants complied with the current 326 laws in their country of origin.

\section{Disclosure statement}

328 The authors declared no potential conflict of interest.

\section{Funding}

330 This Project was partially funded by the Ecos-Nord-CONACYT Program, project number 331 M12A01 granted to CP.

\section{Data availability statement}

333 The datasets generated and/or analyzed during the current study are available from the 334 corresponding author on request.

\section{References}

336 Aguilar-Velasco RG, Poteaux C, Meza-Lázaro R, Lachaud J-P, Dubovikoff D, Zaldívar337 Riverón A. 2016. Uncovering species boundaries in the Neotropical ant complex 338 Ectatomma ruidum (Ectatomminae) under the presence of nuclear mitochondrial 339 paralogues. Zool J Linn Soc. 178:226-240. 
340 Baumann-Pickering S, McDonald MA, Simonis AE, Solsona-Berga A, Merkens KPB, Oleson 341 EM, Roch MA, Wiggins SM, Rankin S, Yack TM, Hildebrand JA. 2013. Species-specific 342 beaked whale echolocation signals. J Acoust Soc Am. 134:2293-2301.

343 Blomquist GJ, Bagnères A-G. 2010. Insect hydrocarbons: biology, biochemistry and chemical ecology. Cambridge (UK): Cambridge University Press; p. 79-81.

345 Brizio C, Buzzetti FM, Pavan G. 2020. Beyond the audible: wide band $(0-125 \mathrm{kHz})$ field 346 investigation on Italian Orthoptera (Insecta) songs. Biodivers J. 11:443-496.

347 Carlos AA, Barbero F, Casacci LP, Bonelli S. 2014. Bioacoustics of Trachymyrmex fuscus, 348 Trachymyrmex tucumanus and Atta sexdens rubropilosa (Hymenoptera: Formicidae). J $349 \quad$ Acoust Soc Am. 136:2074.

350 Castro S, Alvarez M, Mungira ML. 2015. Morphology of the stridulatory organs of Iberian 351 myrmicinae ants (Hymenoptera: Formicidae). Ital J Zool. 82:387-397.

352 Chobanov DP, Grzywacz B, Iorgu IŞ, Ciplak B, Ilieva MB, Warchałowska-Śliwa E. 2013. 353 Review of the Balkan Isophya (Orthoptera: Phaneropteridae) with particular emphasis on 354 the Isophya modesta group and remarks on the systematics of the genus based on 355 morphological and acoustic data. Zootaxa. 3658:1-81.

356 CIBRA: Centro Interdisciplinare di Bioacustica e Ricerche Ambientali. 2017. Pavia, Italy: 357 Università degli Studi di Pavia; [accessed 2021, October 19th]. $358 \quad$ (http://www.unipv.it/cibra/seapro.html)

359 Claridge MF. 1985. Acoustic signals in the Homoptera: behavior, taxonomy and evolution. $360 \quad$ Annu Rev Entomol. 30:297-317.

361 Cocroft RB, Rodríguez RL. 2005. The behavioral ecology of insect vibrational communication. $362 \quad$ BioScience. 55:323-334. 
363 Cupul Magaña FG. 2009. Primera observación del comportamiento defensivo por muerte 364 simulada de la hormiga Ectatomma ruidum (Roger, 1861) (Formicidae, Ponerinae). Acta 365 Zool Mex. 25: 199-201.

366 d'Ettorre P, Moore AJ. 2008. Chemical communication and the coordination of social 367 interactions in insects. In: d'Ettorre P, Hughes DP, editors. Sociobiology of communication: 368 an interdisciplinary perspective. New York: Oxford University Press; p.81-96.

369 Dutta R, Balakrishnan R, Tregenza T. 2018. Divergence in potential contact pheromones and 370 genital morphology among sympatric song types of the bush cricket Mecopoda elongata. $371 \quad$ Front Ecol Evol. 6:158.

372 Endler JA. 1992. Signals, signal conditions, and the direction of evolution. Am Nat. 139:S125$373 \quad$ S153.

374 Ferreira RS, Poteaux C, Delabie JHC, Fresneau D, Rybak F. 2010. Stridulations reveal cryptic 375 speciation in neotropical sympatric ants. PLoS ONE. 5:e15363.

376 Golden TMJ, Hill PSM. 2016. The evolution of stridulatory communication in ants, revisited. $377 \quad$ Insect Soc. 63:309-319.

378 Grandi G. 1966. Istituzioni di Entomologia Generale. Bologna: Calderini; p.655.

379 Grasso DA, Mori A, Le Moli F, Giovannotti M, Fanfani A. 1998. The stridulatory organ of four $380 \quad$ Messor ant species (Hymenoptera, Formicidae). Ital J Zool. 65:167-174.

381 Grasso DA, Priano M, Pavan G, Mori A, Le Moli F. 2000. Stridulation in four species of Messor 382 ants (Hymenoptera: Formicidae). Ital J Zool. 67:281-285.

383 Henry CS, Martínez WM, Pupedis RJ. 1993. Hidden taxonomic diversity within Chrysoperla 384 plorabunda (Neuroptera: Chrysopidae): two new species based on courtship songs. Ann 385 Entomol Soc Am. 86:1-13.

386 Hickling R, Brown RL. 2000. Analysis of acoustic communication by ants. J Acoust Soc Am. 387 108:1920-1929. 
388 Hölldobler B. 1995. The chemistry of social regulation: Multicomponent signals in ant 389 societies. Proc Natl Acad Sci. 92:19-22.

390 Hölldobler B. 1999. Multimodal signals in ant communication. J Comp Physol A. 184:129$391 \quad 141$.

392 Hölldobler B, Wilson EO. 1990. The Ants. Cambridge (MA): Harvard University Press; p. 227393259.

394 Kasper J, Hirschberger P. 2005. Stridulation in Aphodius dung beetles: Songs and morphology 395 of stridulatory organs in North American Aphodius species (Scarabaeidae). J Nat Hist. $396 \quad 39: 91-99$.

397 Lehmann GUC, Frommolt K-H, Lehmann AW, Riede K. 2014. Baseline data for automated 398 acoustic monitoring of Orthoptera in a Mediterranean landscape, the Hymettos, Greece. $\mathbf{J}$ 399 Insect Conserv. 18:909-925.

400 Leonhardt SD, Menzel F, Nehring V, Schmitt T. 2016. Ecology and evolution of 401 communication in social insects. Cell. 164:1277-1287.

402 Lin T-H, Yu H-Y, Chou L-S, Chen C-F. 2014. Passive acoustic monitoring on the seasonal 403 species composition of cetaceans from marine cable hosted observatory. Oceans. IEEE. 1-6. 404 Mahoney SM, Reudink MW, Pasch B, Theimer TC. 2020. Song but not plumage varies 405 geographically among willow flycatcher Empidonax traillii subspecies. J Avian Biol. 51 406 [Accessed 2020 Dec 27] https://doi.org/10.1111/jav.02621

407 Mark1 H. 1965. Stridulation in leaf cutting ants. Science. 149:1392-1393.

408 Masters WM, Tautz J, Fletcher NH, Mark1 H. 1983. Body vibration and sound production in an 409 insect (Atta sexdens) without specialized radiating structures. J Comp Physiol A. 150:239$410 \quad 249$. 
411 McNeil DJ, Grozinger CM. 2020. Singing in the suburbs: point count surveys efficiently reveal 412 habitat associations for nocturnal Orthoptera across an urban-to-rural gradient. J Insect 413 Conserv. 24:1031-1043.

414 Meza-Lázaro RN, Poteaux C, Bayona-Vásquez NJ, Branstetter MG, Zaldívar-Riverón A. 2018. 415 Extensive mitochondrial heteroplasmy in the neotropical ants of the Ectatomma ruidum 416 complex (Formicidae: Ectatomminae). Mitochondrial DNA A. 29:1203-1214.

417 Oswald JN, Rankin S, Barlow J, Lammers MO. 2007. A tool for real-time acoustic species 418 identification of delphinid whistles. J Acoust Soc Am. 122:587-595.

419 Pan AD, Williams KA, Wilson JS. 2017. Are diurnal iguanian lizards the evolutionary drivers 420 of New World female velvet ant (Hymenoptera: Mutillidae) Müllerian mimicry rings? Biol $421 \quad J$ Linn Soc. 120:436-447.

422 Pavan G, Priano M, De Carli P, Fanfani A, Giovannotti M. 1997. Stridulatory organ and 423 ultrasonic emission in certain species of Ponerinae ants (Genus: Ectatomma and 424 Pachycondyla, Hymenoptera, Formicidae). Bioacoustics. 8:209-221.

425 Peña-Carrillo KI, Poteaux C, Leroy C, Meza-Lázaro RN, Lachaud J-P, Zaldívar-Riverón A, 426 Lorenzi MC. 2021. Highly divergent cuticular hydrocarbon profiles in the cleptobiotic ants 427 of the Ectatomma ruidum species complex. Chemoecology. 31:125-135.

428 Polidori C, Pavan G, Ruffato G, Asís JD, Tormos J. 2013. Common features and species429 specific differences in stridulatory organs and stridulation patterns of velvet ants $430 \quad$ (Hymenoptera: Mutillidae) Zool Anz. 252:457-468.

431 Raven Lite: Interactive Sound Analysis Software. Version 2.0.0. Ithaca, NY: The Cornell Lab 432 of Ornithology. URL http://www.birds.cornell.edu/raven.

433 Rheindt FE, Norman JA, Christidis L. 2008. DNA evidence shows vocalizations to be a better 434 indicator of taxonomic limits than plumage patterns in Zimmerius tyrant-flycatchers. Mol $435 \quad$ Phylogenetics Evol. 48:150-156. 
436 Ritchie MG, Gleason JM. 1995. Rapid evolution of courtship song pattern in Drosophila 437 willistoni sibling species. J Evol Biol. 8:463-479.

438 Riva F, Barbero F, Bonelli S, Balleto E, Casacci LP. 2016. The acoustic repertoire of lycaenid 439 butterfly larvae. Bioacoustics. 26:77-90.

440 Roces F, Tautz J, Hölldobler B. 1993. Stridulation in leaf cutting ants. Naturwissenchaften 80: $441 \quad 521-524$.

442 RStudio Team. 2016. RStudio: Integrated Development for R. Version 3.5.2. Boston, MA: 443 RStudio, Inc. URL http://www.rstudio.com/.

444 Schatz B, Lachaud J-P, Beugnon G. 1997. Graded recruitment and hunting strategies linked to 445 prey weight and size in the ponerine ant Ectatomma ruidum. Behav Ecol Sociobiol. 40:337446349.

447 Schmitt M. 1994. Stridulation in leaf beetles (Coleoptera, Chrysomelidae). In: Jolivet PH, Cox 448 ML, Petitpierre E, editors. Novel aspects of the biology of Chrysomelidae. Dordrecht: $449 \quad$ Kluwer Academia Publishers; p.319-325.

450 Schmitt M, Traue D. 1990. Morphological and bioacoustic aspects of stridulation in Criocerinae 451 (Coleoptera Chrysomelidae). Zool Anz. 225:225-240.

452 Schneider CA, Rasband WS, Eliceiri KW. 2012. NIH Image to ImageJ: 25 years of image 453 analysis, Nat methods 9: 671-675.

454 Sueur J, Aubin T, Simonis C. 2008. Seewave: a free modular tool for sound analysis and $455 \quad$ synthesis. Bioacoustics. 18: 213-226.

456 Tan MK, Yong CYH, Ingrisch S, Ahmad Sah HH, Wahab RBHA, Johns PM. 2018. Inferring 457 species boundaries using acoustic and morphological data in the ground cricket genus 458 Gymnogryllus (Orthoptera: Grylloidea: Gryllinae). Syst Biodivers. 16:731-742.

459 Torrico-Bazoberry D, Muñoz MI. 2019. High frequency component in the distress stridulation 460 of Chilean endemic velvet ants (Hymenoptera: Mutillidae). Rev Chil Entomol. 45:5-13. 
461 Tschuch G, Brothers DJ. 1999. Modeling vibration and sound production in insects with 462 nonresonant stridulatory organs. J Acoust Soc Am. 106:3706-3710.

463 van Zweden JS, d'Ettorre P. 2010. Nestmate recognition in social insects and the role of 464 hydrocarbons. In: Blomquist GJ, Bagnères A-G, editors. Insect hydrocarbons: biology, 465 biochemistry and chemical ecology. Cambridge (UK): Cambridge University Press; p. $466 \quad 222-243$.

467 Wilson JS, Williams KA, Forister ML, von Dohlen CD, Pitts JP. 2012. Repeated evolution in 468 overlapping mimicry rings among North American velvet ants. Nat Commun. 3:1272.

469 Wilson JS, Pan AD, Limb ES, Williams KA. 2018. Comparison of African and North American $470 \quad$ velvet ant mimicry complexes: another example of Africa as the 'odd man out'. PLoS ONE. $471 \quad 13: \mathrm{e} 0189482$.

472 Zhantiev RD, Korsunovskaya OS, Benediktov A. 2017. Acoustic signals of the bush-crickets 473 Isophya (Orthoptera: Phaneropteridae) from Eastern Europe, Caucasus and adjacent 474 territories. Eur J Entomol. 114:301-3011. 


\begin{tabular}{|c|c|c|c|c|c|c|}
\hline Species & Locality & State, country & Geographic coordinates & Colony & $\begin{array}{l}\text { Number of individuals } \\
\text { for acoustic analyses }\end{array}$ & $\begin{array}{l}\text { Number of individuals for } \\
\text { morphometric analyses }\end{array}$ \\
\hline \multirow{3}{*}{ sp. 2} & Puerto Morelos & Quintana Roo, Mexico & $20^{\circ} 50^{\prime} 38.82^{\prime \prime} \mathrm{N}, 86^{\circ} 54^{\prime} 11.46 \mathrm{~W}$ & $\begin{array}{c}7 \mathrm{Z} 5 \\
10 \mathrm{Z} 3\end{array}$ & $\begin{array}{l}7 \\
9\end{array}$ & 5 \\
\hline & Coyula & Oaxaca, Mexico & $15^{\circ} 45^{\prime 2} 2.85^{\prime \prime} \mathrm{N}, 96^{\circ} 17^{\prime} 51.05^{\prime \prime} \mathrm{W}$ & Coyula 19 & 5 & 5 \\
\hline & Cali & Cali, Colombia & $3^{\circ} 22^{\prime} 39^{\prime \prime} \mathrm{N}, 76^{\circ} 31^{\prime} 52^{\prime \prime} \mathrm{W}$ & $\begin{array}{l}118 \\
92\end{array}$ & $\begin{array}{c}10 \\
7\end{array}$ & 6 \\
\hline \multirow{4}{*}{ sp. 3-4 } & $\begin{array}{l}\text { Puerto Escondido } \\
\text { (Yerba Santa) }\end{array}$ & Oaxaca, Mexico & $15^{\circ} 56^{\prime} 24^{\prime \prime N}, 97^{\circ} 4^{\prime} 15.60^{\prime \prime} \mathrm{W}$ & YS1 & 7 & 5 \\
\hline & Piedras Negras & Oaxaca, Mexico & $15^{\circ} 43^{\prime} 30^{\prime \prime} \mathrm{N}, 96^{\circ} 39^{\prime} 36.00^{\prime \prime} \mathrm{W}$ & 17 & 5 & 5 \\
\hline & Mazunte (Puente Zapotal) & Oaxaca, Mexico & $15^{\circ} 41^{\prime} 6^{\prime} \mathrm{N}, 96^{\circ} 33^{\prime} 54^{\prime \prime} \mathrm{W}$ & 6 & 6 & 5 \\
\hline & Punto3 & Oaxaca, Mexico & $15^{\circ} 57^{\prime} 24.84^{\prime \prime} \mathrm{N}, 97^{\circ} 11^{\prime} 46.32^{\prime \prime} \mathrm{W}$ & Punto3 & 9 & 5 \\
\hline \multirow{3}{*}{ sp. 5} & \multirow{3}{*}{ Huaxpaltepec } & \multirow{3}{*}{ Oaxaca, Mexico } & \multirow{3}{*}{$16^{\circ} 20^{\prime} 26.00^{\prime \prime} \mathrm{N}, 97^{\circ} 57^{\prime} 34.00^{\prime \prime} \mathrm{W}$} & $\begin{array}{l}\text { Huax13 } \\
\text { Huax1-1 }\end{array}$ & $\begin{array}{l}5 \\
5\end{array}$ & 6 \\
\hline & & & & Huax2-8 & 5 & - \\
\hline & & & & Huax2-14 & 5 & - \\
\hline
\end{tabular}


478 Table 2. Mean values \pm standard error and min-max range (between parentheses) of the stridulatory sound variables of the E. ruidum species 2, 3-4 and 5. Measures are given in seconds (duration) or per second (number or rate)

\begin{tabular}{lccc}
\hline \hline & E. ruidum sp. 2 & E. ruidum sp. 3-4 & E. ruidum sp. 5 \\
\hline \multirow{2}{*}{ Chirp duration } & $0.248 \pm 0.006$ & $0.229 \pm 0.005$ & $0.390 \pm 0.018$ \\
& $(0.069-0.602)$ & $(0.094-0.389)$ & $(0.173-1.132)$ \\
\hline \multirow{2}{*}{ Duration of forward phase } & $0.112 \pm 0.003$ & $0.105 \pm 0.003$ & $0.190 \pm 0.011$ \\
& $(0.032-0.321)$ & $(0.036-0.231)$ & $(0.082-0.707)$ \\
\hline \multirow{2}{*}{ Duration of backward phase } & $0.112 \pm 0.003$ & $0.101 \pm 0.003$ & $0.169 \pm 0.006$ \\
& $(0.024-0.347)$ & $(0.034-0.208)$ & $(0.068-0.405)$ \\
\hline \multirow{2}{*}{ Inter chirp duration (GAP) } & $0.024 \pm 0.001$ & $0.023 \pm 0.001$ & $0.032 \pm 0.002$ \\
& $(0.010-0.066)$ & $(0.009-0.079)$ & $(0.010-0.114)$ \\
Number of forward pulses & $66 \pm 2$ & $59 \pm 2$ & $112 \pm 4$ \\
& $(16-176)$ & $(13-135)$ & $(41-248)$ \\
Number of backward pulses & $81 \pm 3$ & $68 \pm 2$ & $115 \pm 3$ \\
& $(22-196)$ & $(19-142)$ & $(37-224)$ \\
Total number of pulses & $147 \pm 4$ & $127 \pm 3$ & $226 \pm 7$ \\
& $(40-338)$ & $(50-232)$ & $(99-442)$ \\
Chirp rate & $4.51 \pm 0.12$ & $4.62 \pm 0.10$ & $2.96 \pm 0.01$ \\
& $(1.66-14.57)$ & $(2.57-10.67)$ & $(0.88-5.78)$ \\
Average pulse rate of forward phase & $609 \pm 18$ & $591 \pm 19$ & $672 \pm 25$ \\
& $(183-1497)$ & $(194-1231)$ & $(257-1491)$ \\
Average pulse rate of backward phase & $620 \pm 20$ & $641 \pm 30$ & $730 \pm 30$ \\
& $(107-1669)$ & $(120-2027)$ & $(208-1642)$ \\
\hline Total number of ants & 38 & 27 & 20 \\
\hline \hline
\end{tabular}


482 Table 3. The percentage of rubbed ridges and the speed of the rubbing movement of the E. ruidum species 2, 3-4 and 5 (Mean \pm standard error (min-max range).

\begin{tabular}{cccc}
\hline \hline & E. ruidum sp. 2 & E. ruidum sp. 3-4 & E. ruidum sp. 5 \\
Percentage of rubbed ridges during the forward phase & $32 \pm 3$ & $29 \pm 2$ & $66 \pm 12$ \\
& $(17-56)$ & $(15-42)$ & $(41-107)$ \\
Percentage of rubbed ridges during the backward phase & $39 \pm 3$ & $34 \pm 2$ & $64 \pm 9$ \\
& $(20-59)$ & $(20-48)$ & $(42-94)$ \\
\hline \multirow{2}{*}{ Speed of the forward rubbing movement $(\mu \mathrm{m} / \mathrm{msec})$} & $1.12 \pm 0.12$ & $1.12 \pm 0.10$ & $0.804 \pm 0.042$ \\
Speed of the backward rubbing movement $(\mu \mathrm{m} / \mathrm{msec})$ & $(0.526-1.81)$ & $(0.513-1.83)$ & $(0.729-0.968)$ \\
Total number of ants & $(0.70 \pm 0.17$ & $1.34 \pm 0.07$ & $0.989 \pm 0.075$ \\
\hline \hline
\end{tabular}


490 Table 4. Scores of the PCA factor loadings on the acoustical traits of worker ants (only $r>0.700$ ). The variables are sorted by loading size. High loadings indicated that the trait 491 was highly correlated with the PC.

\begin{tabular}{lcc}
\hline \hline \multicolumn{1}{c}{ Rotated Component Matrix } & \multicolumn{2}{c}{ Principal Component } \\
\cline { 2 - 3 } & 1 & 2 \\
\hline Total number of pulses & 0.965 & - \\
Number of forward pulses & 0.886 & - \\
Number of backward pulses & 0.869 & - \\
GAP duration & - & 0.891 \\
Total chirp duration & - & 0.824 \\
Forward chirp duration & - & 0.760 \\
\hline \hline
\end{tabular}

\section{2}


494 Table 5. Mean values \pm standard error (and min-max range in parentheses) of the morphometric variables of the stridulatory file of the E. ruidum species 2, 3-4 and 5.

\begin{tabular}{|c|c|c|c|c|}
\hline \multirow[b]{2}{*}{497} & Workers & E. ruidum sp. 2 & E. ruidum sp. 3-4 & E. ruidum sp. 5 \\
\hline & Thorax lenght $(\mu \mathrm{m})$ & $\begin{array}{c}2891 \pm 86 \\
(2192-3352)\end{array}$ & $\begin{array}{c}3252 \pm 50 \\
(2836-3607)\end{array}$ & $\begin{array}{c}2912 \pm 63 \\
(2640-3101)\end{array}$ \\
\hline 498 & $\begin{array}{l}\text { Stridulatory file } \\
\text { total length }(\mu \mathrm{m})\end{array}$ & $\begin{array}{c}352 \pm 9 \\
(279-404)\end{array}$ & $\begin{array}{c}390 \pm 6 \\
(359-453)\end{array}$ & $\begin{array}{c}376 \pm 13 \\
(339-421)\end{array}$ \\
\hline \multirow{2}{*}{499} & Maximal width $(\mu \mathrm{m})$ & $\begin{array}{c}270 \pm 16 \\
(75.5-336)\end{array}$ & $\begin{array}{c}266 \pm 8 \\
(191-317)\end{array}$ & $\begin{array}{c}293 \pm 6 \\
(274-316)\end{array}$ \\
\hline & Q1 width $(\mu \mathrm{m})$ & $\begin{array}{c}233 \pm 10 \\
(158-306)\end{array}$ & $\begin{array}{c}225 \pm 8 \\
(165-291)\end{array}$ & $\begin{array}{c}202 \pm 6 \\
(185-219)\end{array}$ \\
\hline 500 & Q2 width $(\mu \mathrm{m})$ & $\begin{array}{c}275 \pm 10 \\
(200-356)\end{array}$ & $\begin{array}{c}260 \pm 7 \\
(183-304)\end{array}$ & $\begin{array}{c}286 \pm 6 \\
(270-310)\end{array}$ \\
\hline 501 & Q3 width $(\mu \mathrm{m})$ & $\begin{array}{c}220 \pm 10 \\
(145-295)\end{array}$ & $\begin{array}{c}231 \pm 7 \\
(146-285)\end{array}$ & $\begin{array}{c}256 \pm 8 \\
(236-280)\end{array}$ \\
\hline 502 & Total number of ridges & $\begin{array}{c}192 \pm 5 \\
(160-238)\end{array}$ & $\begin{array}{c}199 \pm 3 \\
(176-219)\end{array}$ & $\begin{array}{c}193 \pm 4 \\
(177-202)\end{array}$ \\
\hline \multirow[t]{2}{*}{503} & $\begin{array}{c}\text { Mean of distance } \\
\text { between ridges }(\mu \mathrm{m})\end{array}$ & $\begin{array}{c}0.298 \pm 0.018 \\
(0.223-0.515)\end{array}$ & $\begin{array}{c}0.349 \pm 0.019 \\
(0.218-0.557)\end{array}$ & $\begin{array}{c}0.298 \pm 0.011 \\
(0.250-0.326)\end{array}$ \\
\hline & Total & 16 & 20 & 6 \\
\hline
\end{tabular}


506 Table 6. Scores of the PCA factor loadings on the morphometric traits (only $r>0.700$ ). The variables are sorted by loading size. High loadings indicated that the trait was highly 507 correlated with the PC.

\begin{tabular}{lcc}
\hline \multicolumn{1}{c}{ Rotated Component Matrix } & Principal Component \\
& 1 & 2 \\
Q2 width & 0.891 & - \\
Q1 width & 0.801 & - \\
Maximal width of stridulatory file & 0.761 & - \\
Total length of stridulatory file & - & 0.887 \\
Total number of ridges & - & 0.845 \\
Thorax lenght & - & 0.805 \\
\hline \hline
\end{tabular}




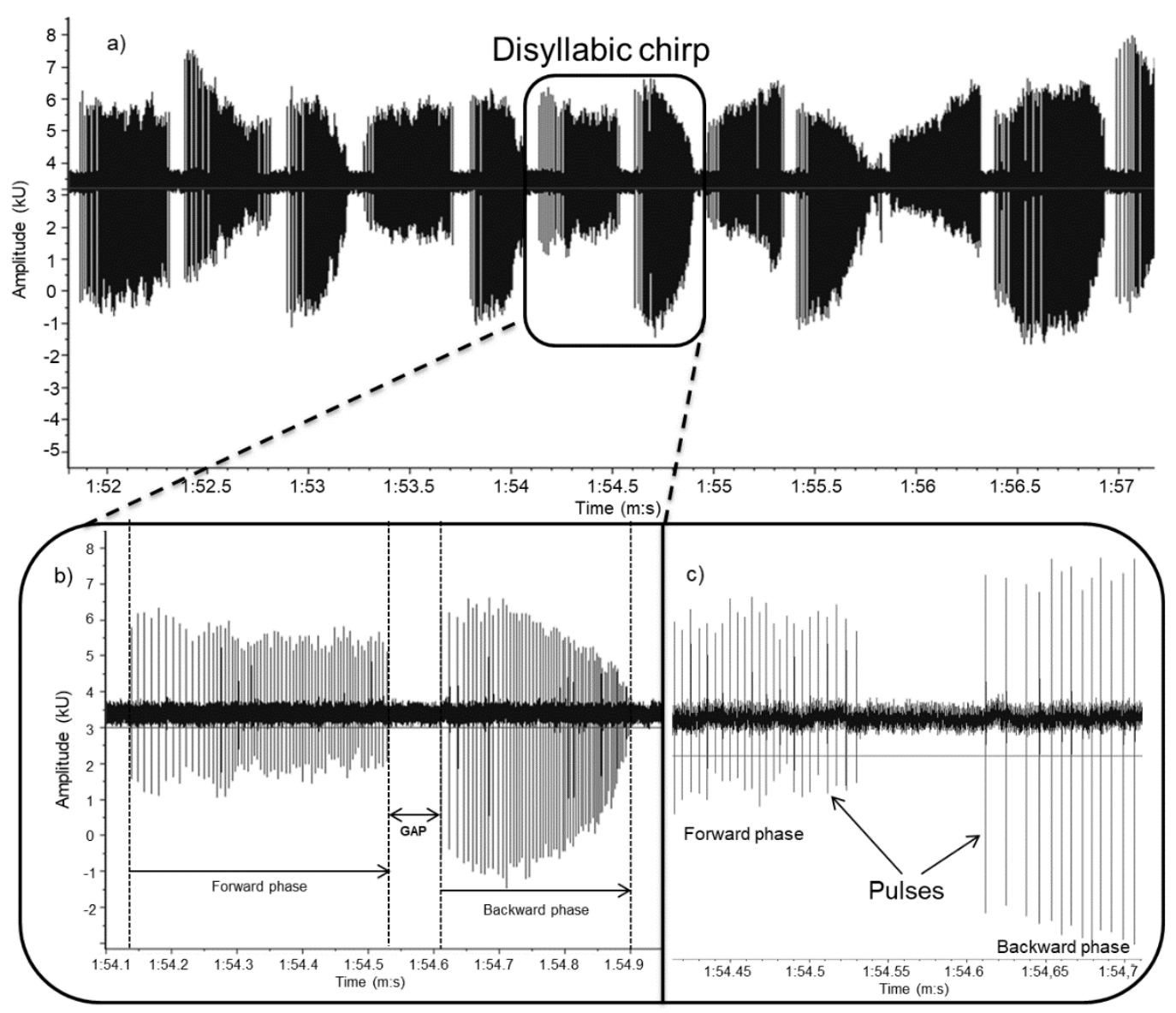

$511 \quad$ Figure 1.

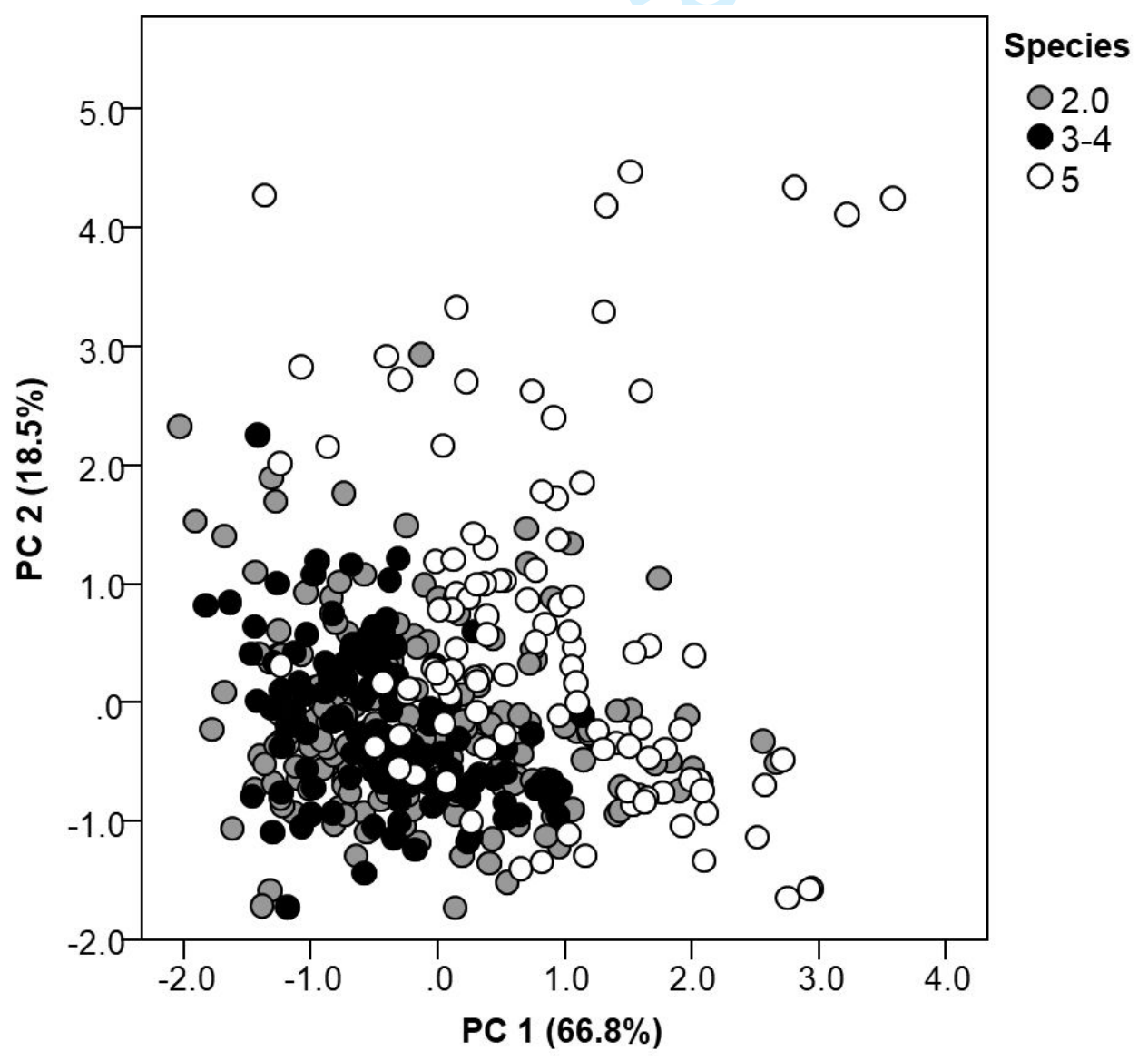

512

Figure 2. 

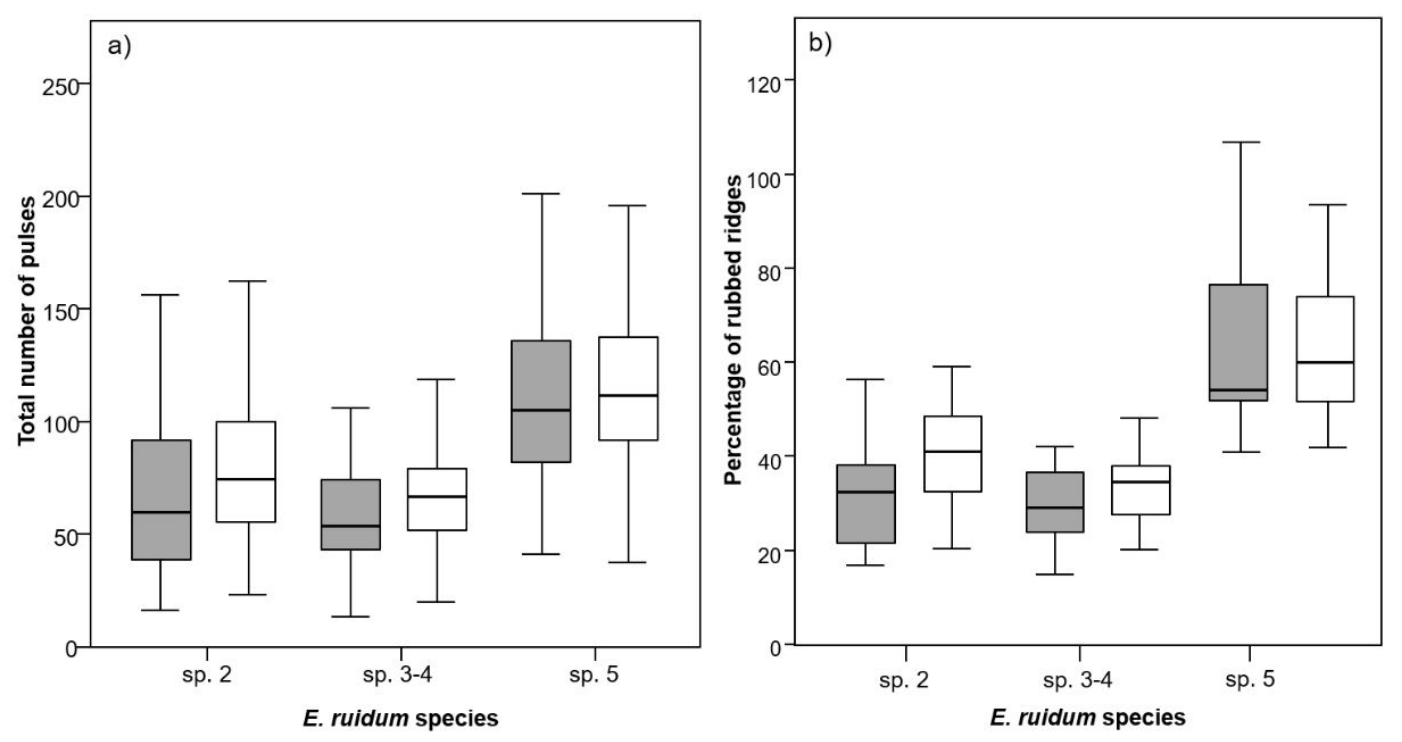

515

$516 \quad$ Figure 3.
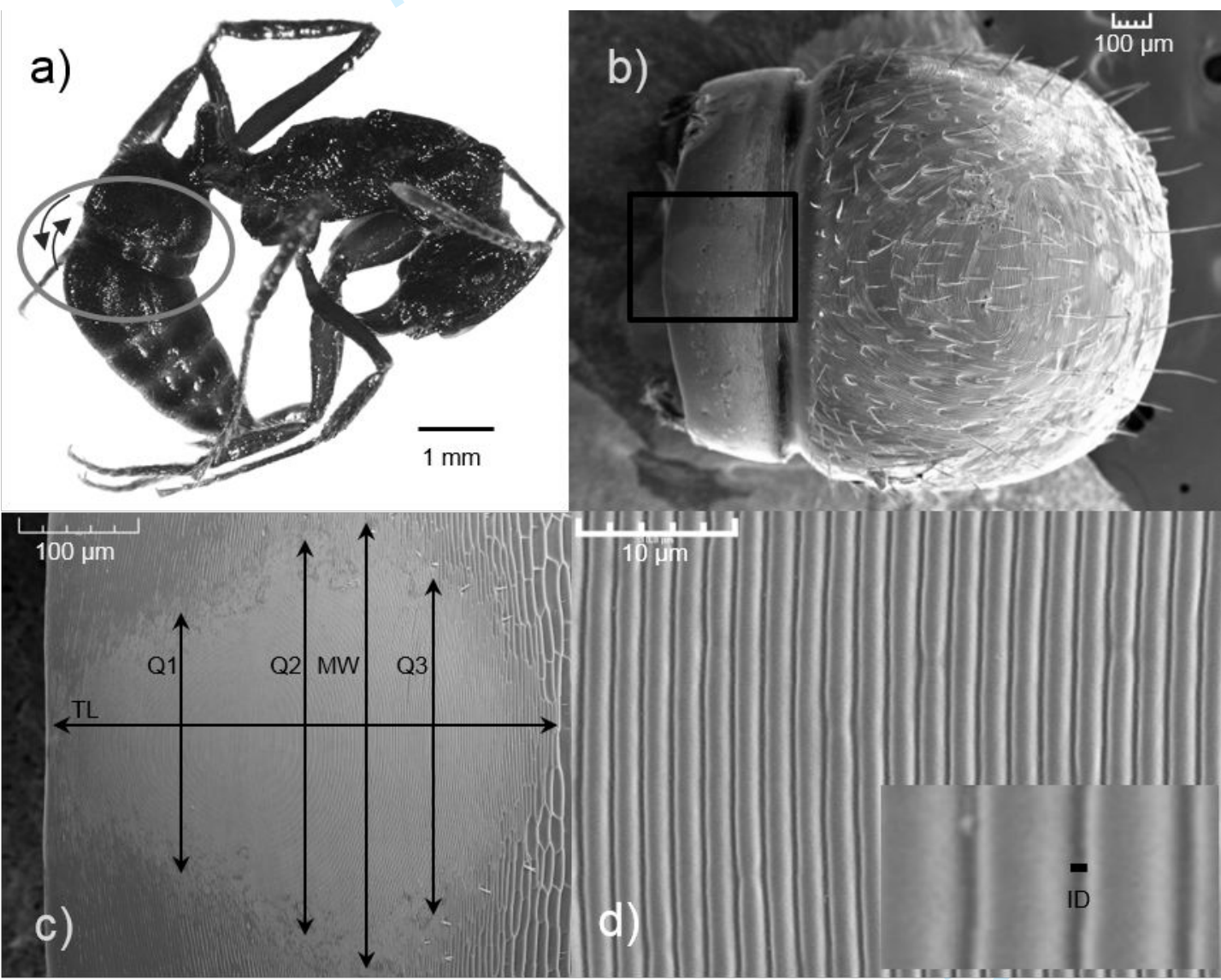

517

$518 \quad$ Figure 4.

519 
520 Figure 1. (a) A sequence of disyllabic chirps in the E. ruidum stridulation. (b) Detailed view of a 521 disyllabic chirp: forward phase, backward phase and the GAP (time space in between forward and 522 backward phases). (c) Detailed view of pulses of the forward and backward phase around the gap 523 from minute $1: 54.45$ to $1: 54.7$.

524 Figure 2. PCA's plot of the acoustical traits in the three species of the E. ruidum complex.

525 Figure 3. Acoustic variation of E. ruidum. (a) Total number of pulses per phase and species (b) 526 Percentage of rubbed ridges per phase and species during the stridulation; bars colored with gray 527 background represent the forward phase and bars with white background the backward phase of 528 the chirps.

529 Figure 4. The stridulatory file in E. ruidum. (a) Position of the file in the gaster; arrows indicate 530 the backward and forward movement of the gaster when stridulating. (b) Postpetiolar segment of 531 the gaster where the stridulatory file is located. (c) Morphometric variables taken from the 532 stridulatory file: total length of stridulatory file (TL), maximal width (MW), $1^{\text {st }}, 2^{\text {nd }}$ and $3^{\text {rd }}$ quartile 533 widths (Q1, Q2, Q3, respectively). (d) Ridges in the stridulatory file and focus on the inter-ridge 534 distance measure (ID). 


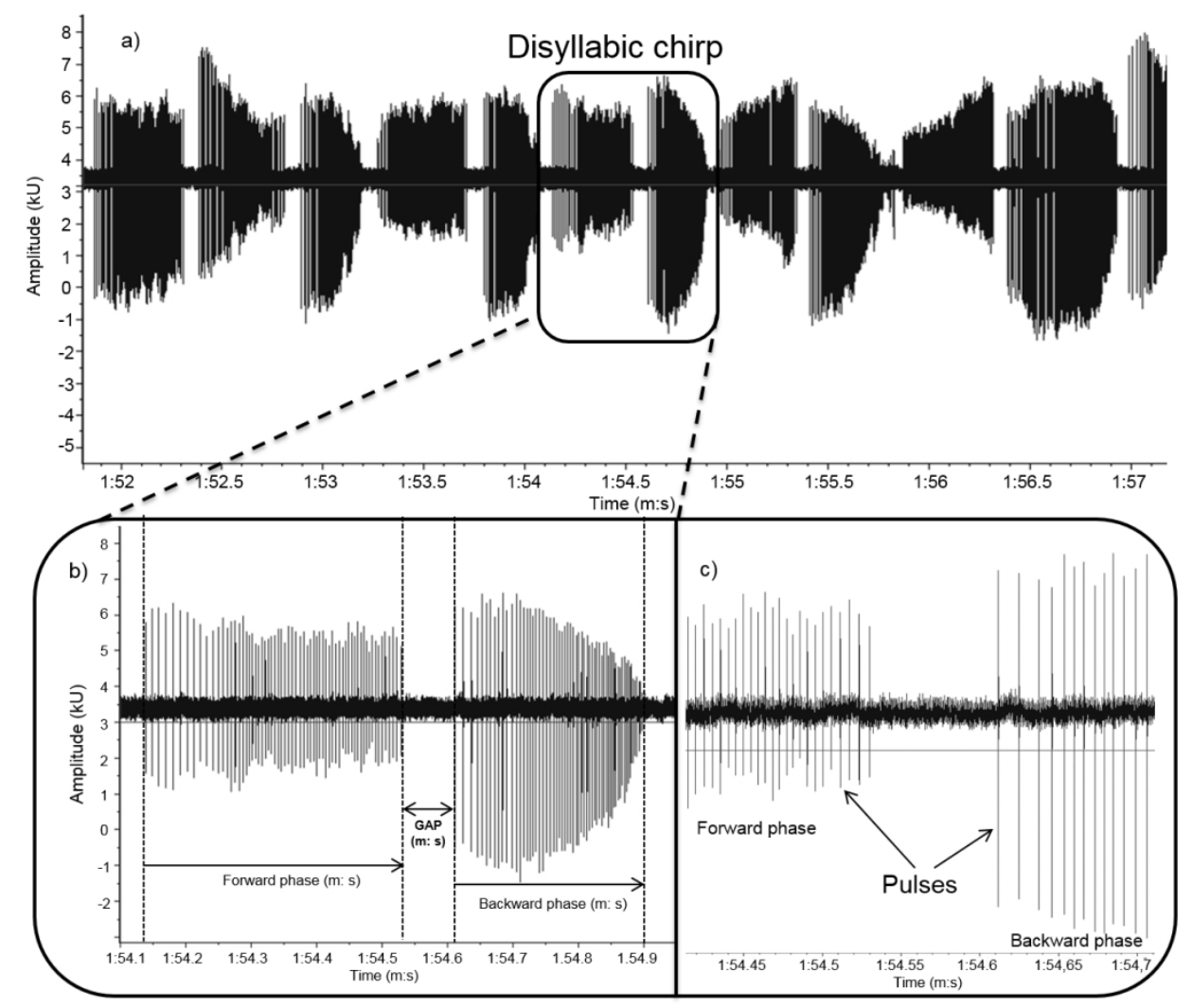

Figure 1. (a) A sequence of disyllabic chirps in the E. ruidum stridulation. (b) Detailed view of a disyllabic chirp: forward phase, backward phase and the GAP (time space in between forward and backward phases).

(c) Detailed view of pulses of the forward and backward phase around the gap from minute 1:54.45 to $1: 54.7$.

$241 \times 195 \mathrm{~mm}(150 \times 150 \mathrm{DPI})$ 


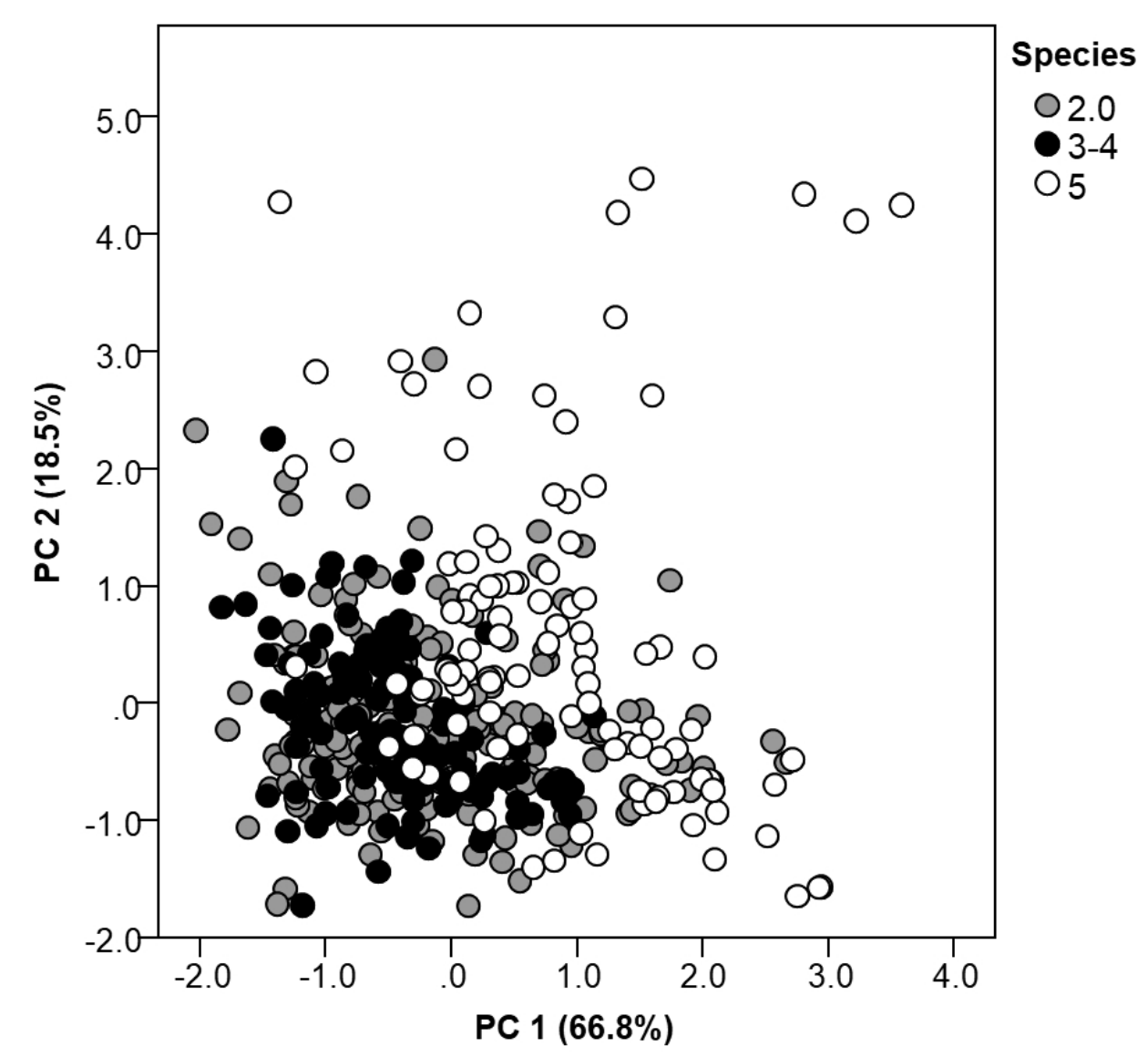

Figure 2. PCA's plot of the acoustical traits in the three species of the E. ruidum complex.

$164 \times 146 \mathrm{~mm}(150 \times 150 \mathrm{DPI})$ 

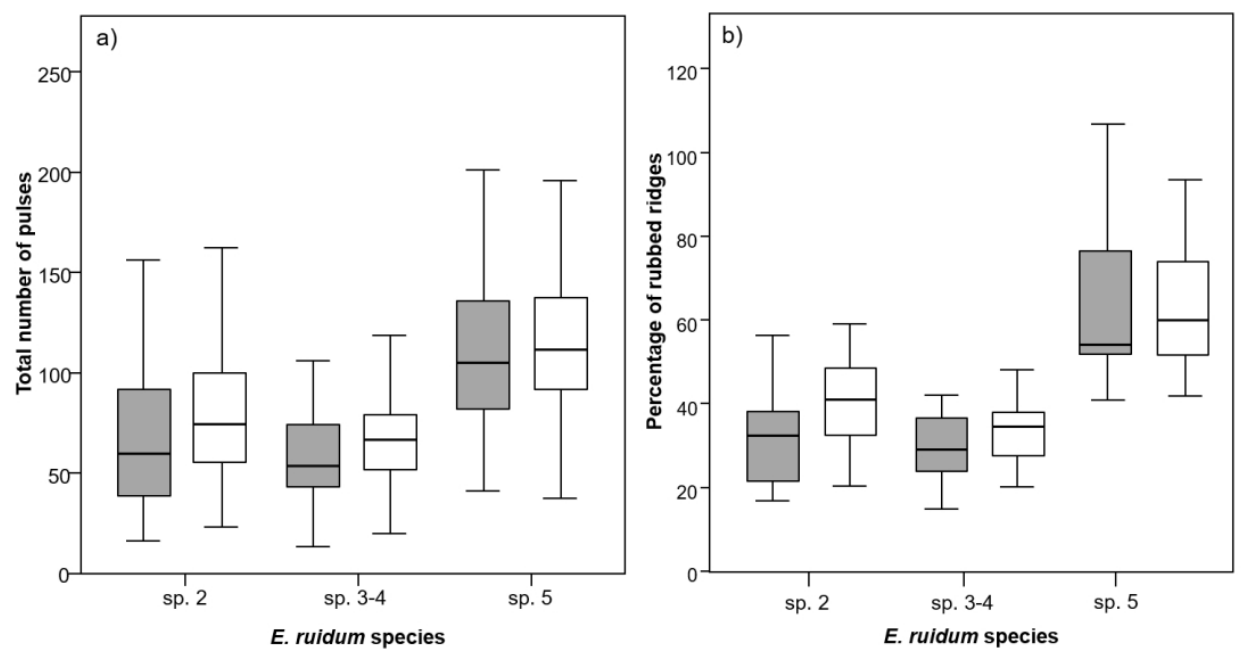

Figure 3. Acoustic variation of E. ruidum. (a) Total number of pulses per phase and species (b) Percentage of rubbed ridges per phase and species during the stridulation; bars colored with gray background represent the forward phase and bars with white background the backward phase of the chirps.

$268 \times 141 \mathrm{~mm}(150 \times 150 \mathrm{DPI})$ 


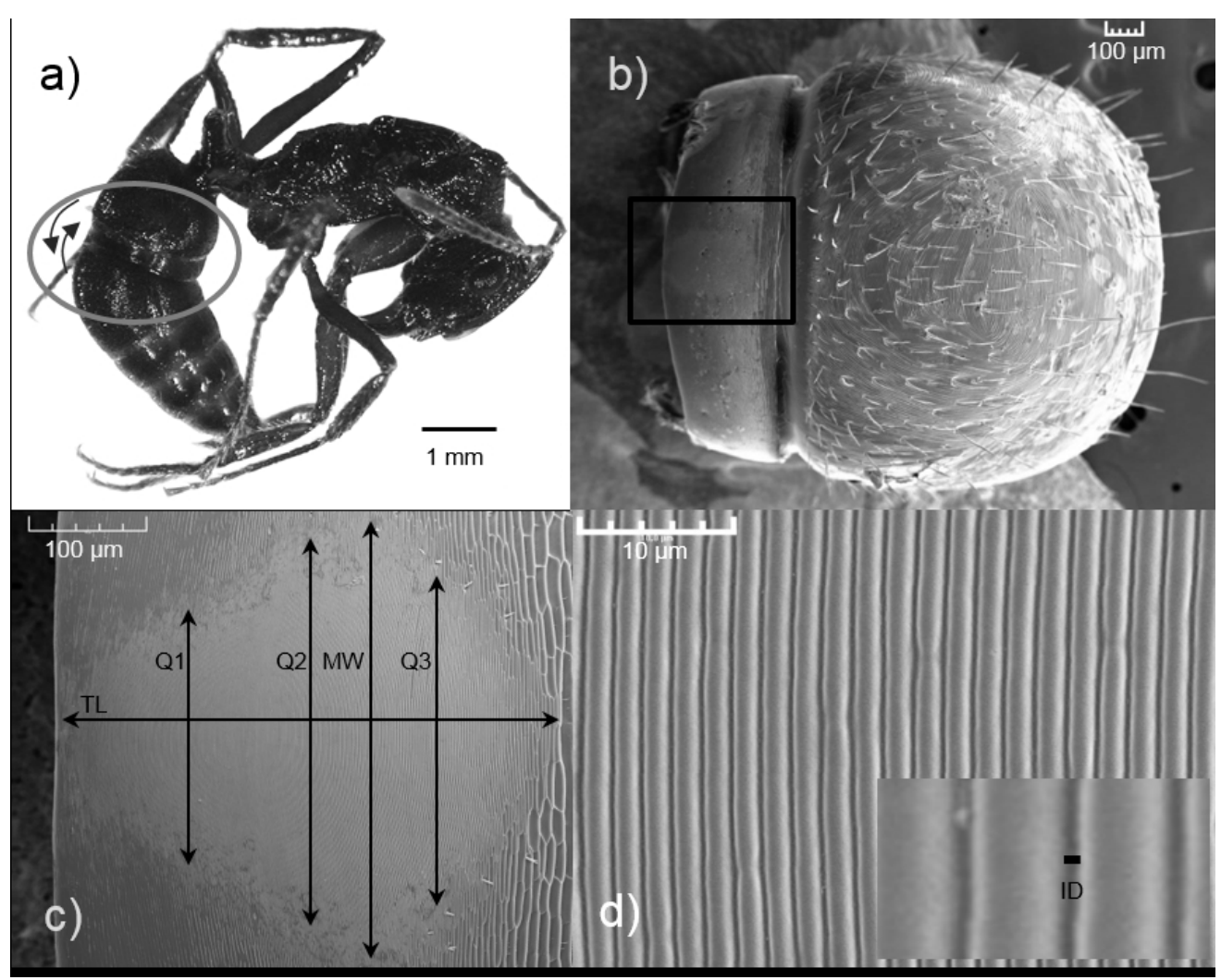

Figure 4. The stridulatory file in E. ruidum. (a) Position of the file in the gaster; arrows indicate the backward and forward movement of the gaster when stridulating. (b) Postpetiolar segment of the gaster where the stridulatory file is located. (c) Stridulatory file and its measures. (d) Ridges in the stridulatory file and focus on the inter-ridge distance measure.

$145 \times 115 \mathrm{~mm}(150 \times 150 \mathrm{DPI})$ 